\title{
Pemantauan pH Esofagus pada Bayi Tidak Mempengaruhi Aktivitas dan Pola Makan, Namun Mengkhawatirkan Persepsi Orangtua
}

\author{
Badriul Hegar, Setia Budi, Muzal Kadim, Agus Firmansyah
}

\begin{abstract}
Latar belakang. Pemantauan $\mathrm{pH}$ esofagus ( $\mathrm{pH}$-metri) merupakan pemeriksaan baku untuk mendiagnosis refluks gastroesofagus (RGE) pada bayi. Hasil $\mathrm{pH}$-metri dipengaruhi oleh pola makan dan aktivitas bayi, sedangkan pengaruh prosedur $\mathrm{pH}$-metri itu sendiri terhadap pola makan dan aktivitas bayi belum banyak dilaporkan.

Tujuan. Tujuan penelitian ini untuk mengetahui apakah prosedur $\mathrm{pH}$-metri mempengaruhi pola makan dan aktivitas sehari-hari serta bagaimana persepsi orangtua terhadap prosedur $\mathrm{pH}$-metri.

Metoda. Tiga puluh bayi berumur 6-12 bulan dilakukan $\mathrm{pH}$-metri. Orangtua diberi kuesioner berisi pertanyaan yang berhubungan dengan pola makan dan aktivitas anak selama pemantauan berlangsung serta persepsi orangtua terhadap prosedur $\mathrm{pH}$-metri. Untuk analisis statistik, setiap variabel dikelompokkan menjadi 'tidak berubah' dan 'berubah' untuk pola makan dan aktivitas anak, serta 'positif dan 'negatif' untuk persepsi orangtua. Setiap variabel dianalisis berdasarkan hasil $\mathrm{pH}$-metri ('normal' atau abnormal'). Hasil. Perubahan pola makan terdapat pada $17 \%$ bayi sedangkan perubahan aktivitas pada $20 \%$ bayi. Kedua hasil tersebut tidak berbeda baik pada hasil $\mathrm{pH}$-metri normal maupun hasil $\mathrm{pH}$-metri abnormal. Dua puluh tujuh persen orangtua mempunyai persepsi positif terhadap prosedur $\mathrm{pH}$-metri.

Kesimpulan. Prosedur $\mathrm{pH}$-metri tidak menyebabkan perubahan pola makan dan aktivitas bayi, walaupun demikian hanya sekitar $27 \%$ orangtua yang menganggap prosedur $\mathrm{pH}$-metri sebagai prosedur yang tidak mengkhawatirkan.
\end{abstract}

Kata kunci: pH-metri, refluks gastroesofagus, pola makan, aktivitas bayi, persepsi orangtua

61

efluks gastroesofagus (RGE) adalah kembalinya isi lambung ke dalam esofagus yang terjadi secara involunter. Berbagai gejala klinis dapat diperlihatkan oleh bayi yang mengalami RGE, dan regurgitasi merupakan manifestasi klinis

Alamat korespondensi:

Dr. Badriul Hegar, Sp.A.(K)

Divisi Gastroenterologi. Departemen Ilmu Kesehatan Anak FKUI-

RSCM. Jl. Salemba no. 6, Jakarta 10430.

Telepon: 021-3915665. Fax.021-390 7743 . yang paling sering ditemukan. Regurgitasi didefinisikan sebagai keluarnya isi refluks tersebut melalui mulut. Refluks gastroesofagus fisiologis terjadi apabila bayi tumbuh normal tanpa adanya gejala klinis komplikasi (esofagitis). ${ }^{1,2}$ Pemantauan $\mathrm{pH}$ esofagus (pH-metri) sampai saat ini merupakan pemeriksaan standar untuk mendiagnosis RGE, karena dapat mendeteksi episode refluks dan lamanya perubahan $\mathrm{pH}$ di dalam lumen esofagus. Teknik tersebut telah lama digunakan di negara maju dan beberapa negara di Asia. Selama ini diketahui bahwa aktivitas dan pola makan bayi mempengaruhi hasil pH-metri, ${ }^{3,4}$ 
sedangkan pengaruh prosedur $\mathrm{pH}$ metri terhadap aktivitas dan pola makan bayi serta hubungan antara perubahan aktivitas dan pola makan dengan hasil $\mathrm{pH}$ metri belum banyak dilaporkan.

Di Indonesia, $\mathrm{pH}$-metri relatif baru diperkenalkan sejak tahun 1998. Oleh karena itu cukup beralasan dilakukan penelitian pendahuluan yang bertujuan selain untuk mengetahui pengaruh prosedur $\mathrm{pH}$-metri terhadap pola makan dan aktivitas anak, juga untuk mengetahui persepsi orangtua terhadap prosedur $\mathrm{pH}$ metri.

\section{Metoda}

Dalam penelitian ini tiga puluh bayi yang dilakukan $\mathrm{pH}$-metri. Kriteria inklusi penelitian mencakup bayi berumur 6-12 bulan, regurgitasi berlebihan (lebih dari 4 kali per hari), rasio berat badan (BB) terhadap panjang badan $(\mathrm{PB})>90 \%$, tidak ada gejala klinis esofagitis (rewel, menolak minum/makan, hematemesis/melena, back arching), dan secara klinis tidak ditemukan kelainan yang mengganggu pola makan dan aktivitas bayi.

Sebelum dilakukan $\mathrm{pH}$-metri, orangtua diberi penjelasan tentang tahapan prosedur yang akan dilakukan dan diyakinkan bahwa pemeriksaan yang akan dilakukan merupakan prosedur rutin pada RGE. Setelah orangtua paham tentang penjelasan yang diberikan dan menyetujui anaknya diikutsertakan dalam penelitian, maka orangtua diminta untuk menandatangani informed consent. Pasien dirawat sehari dan orangtua diberi formulir yang berisi aktivitas dan kejadian selama pemeriksaan $\mathrm{pH}$-metri berlangsung.

Pemantauan $\mathrm{pH}$ esofagus dilakukan sesuai dengan protokol standar kelompok kerja European Society of Pediatric Gastroenterology Hepatology and Nutrition (ESPGHAN). Prosedur pH-metri dimulai dengan memasukkan kateter yang mempunyai elektroda pada ujungnya ( $\mathrm{pH}$ antimony monocrystant semidisposabel, Medtronic Synectics, Swedia) ke dalam esofagus sampai setinggi 2 vertebra di atas diafragma (lokasi elektrode tersebut dibuktikan dengan pemeriksaan fluoroskopi). Pangkal kateter dihubungkan dengan alat digitraper MK III (Synectics Medical AB, Swedia). Pemantauan $\mathrm{pH}$ esofagus dilakukan selama 24 jam. ${ }^{5}$ Data dianalisis dengan menggunakan esofagogram gastrosoft dan polygram windows. Hasil $\mathrm{pH}$-metri dikatakan normal bila nilai indeks refluks (IR) $\leq 5 \%$ dan abnormal bila IR > 5\% (indeks refuks adalah persentase keseluruhan waktu pemantauan dengan $\mathrm{pH}$ esofagus < 4). ${ }^{6}$

Setelah pemeriksaan $\mathrm{pH}$-metri selesai, peneliti yang tidak mengetahui hasil $\mathrm{pH}$-metri meminta kepada orang tua untuk menjawab kuesioner. Kuesioner yang digunakan merupakan modifikasi dari kuesioner yang digunakan oleh Arana dkk. ${ }^{7}$ Kuesioner berisi beberapa pertanyaan untuk melihat pengaruh prosedur $\mathrm{pH}$-metri terhadap aktivitas dan pola makan anak serta persepsi orangtua terhadap prosedur $\mathrm{pH}$-metri (Tabel 1 ).

Tabel 1. Kuesioner

Pola makan

- Apakah jadwal makan anak anda seperti biasanya?

- Apakah jenis makanan dan minuman anak anda seperti biasanya?

- Apakah jumlah makanan dan minuman yang dikonsumsi anak anda seperti biasanya ?

Aktivitas sehari-hari

- Apakah aktivitas anak anda seperti biasanya?

- Apakah pola tidur anak anda seperti biasanya ?

- Apakah anak anda tidur lelap (tidak suka terbangun) seperti biasanya ?

Persepsi orangtua terhadap pemeriksaan $\mathrm{pH}$-metri

- Apakah ibu/bapak merasa nyaman dengan prosedur pH-metri yang dilakukan ?

- Apakah anak ibu/bapak dapat mentoleransi pemeriksaan ini lebih dari yang ibu/bapak bayangkan sebelumnya?

- Apakah pemeriksaan ini memang diperlukan untuk menentukan diagnosis dan pengobatan anak ibu/bapak? 
Setiap jawaban 'ya' diberi nilai 1 dan jawaban 'tidak' diberi nilai 0 . Setelah semua pertanyaan untuk kelompok pola makan dan aktivitas sehari-hari dijawab oleh orangtua, peneliti memperlihatkan dan menjelaskan hasil pH-metri kepada orangtua. Selanjutnya, orangtua diminta untuk menjawab kuesioner dari kelompok persepsi orangtua terhadap prosedur $\mathrm{pH}$-metri.

Setiap kelompok pertanyaan diberi skor 0 sampai 3. Untuk kelompok pola makan dan aktivitas seharihari, skor di atas 1 (skor 2 atau 3) berarti pH-metri tidak mengubah pola makan dan aktivitas anak, sedangkan skor 1 atau skor 0 berarti $\mathrm{pH}$-metri mengubah pola makan dan aktivitas anak. Untuk persepsi orangtua, skor di atas 1 (skor 2 atau 3) berarti prosedur $\mathrm{pH}$-metri tidak menimbulkan kekhawatiran orangtua (persepsi positif), sedangkan skor 1 dan 0 berarti prosedur $\mathrm{pH}$-metri menimbulkan kehawatiran orangtua (persepsi negatif). Hasil kuesioner juga dianalisis berdasarkan hasil $\mathrm{pH}$-metri (normal atau abnormal). Selain itu, orangtua ditanyakan pula tentang pengalaman sebelumnya dengan prosedur $\mathrm{pH}$ metri. Uji statistik menggunakaan chi-squre dengan tingkat signifikansi 5\%.

\section{Hasil}

Dari 30 bayi (umur 'rerata' 8,8 bulan) yang ikut dalam penelitian didapatkan $17 \%$ (5/30) anak dengan pola makan berubah dan $20 \%(6 / 30)$ anak dengan aktivitas berubah selama prosedur $\mathrm{pH}$-metri berlangsung. Pada hasil $\mathrm{pH}$-metri didapatkan 53\% bayi mempunyai $\mathrm{pH}$-metri normal dan sisanya (47\%) mempunyai hasil pH-metri abnormal (Tabel 2).

Perubahan pola makan dan aktivitas sehari-hari tidak berbeda baik pada kelompok bayi dengan hasil pH-metri normal maupun pada kelompok bayi dengan hasil $\mathrm{pH}$-metri abnormal. Dari 16 bayi dengan $\mathrm{pH}$ metri normal, $81 \%$ diantaranya tidak memperlihatkan perubahan pola makan. Begitu pula dari 14 bayi dengan $\mathrm{pH}$-metri abnormal, 86\% diantaranya tidak memperlihatkan perubahan pola makan. Kedua hasil tersebut tidak berbeda bermakna secara statistik ( $>0,05)$ (Tabel 3).

Dari 16 bayi dengan hasil $\mathrm{pH}$-metri normal, 88\% diantaranya tidak memperlihatkan perubahan aktivitas, sedangkan pada bayi dengan $\mathrm{pH}$-metri abnormal didapatkan $71 \%$ bayi dengan aktivitas sehari-hari tidak berubah. Kedua hasil tersebutpun tidak berbeda bermakna secara statistik ( $>0,05)$ (Tabel 4).

Terlepas dari hasil $\mathrm{pH}$-metri, $73 \%$ orangtua berpendapat bahwa prosedur $\mathrm{pH}$-metri merupakan

Tabel 2. Hasil pH-metri

\begin{tabular}{lcc}
\hline pH-metri & Jumlah $(\mathbf{n})$ & Persentase ( \% ) \\
\hline Normal & 16 & 53 \\
Abnormal & 14 & 47 \\
\hline Jumlah & 30 & 100 \\
\hline
\end{tabular}

Tabel 3. Hubungan hasil $\mathrm{pH}$-metri dengan pola makan

\begin{tabular}{|c|c|c|c|c|c|}
\hline \multirow[t]{2}{*}{ pH-metri } & \multicolumn{4}{|c|}{ Pola makan } & \multirow{2}{*}{$\begin{array}{c}\text { Jumlah } \\
\mathrm{N}\end{array}$} \\
\hline & Tidak berubah & $\%$ & Berubah & $\%$ & \\
\hline Normal & 13 & 81 & 3 & 19 & 16 \\
\hline Abnormal & 12 & 86 & 2 & 14 & 14 \\
\hline Jumlah & 25 & 83 & 5 & 17 & 30 \\
\hline
\end{tabular}

Tabel 4. Hubungan hasil $\mathrm{pH}$-metri dengan aktivitas sehari-hari

\begin{tabular}{lccccc}
\hline \multirow{2}{*}{ pH-metri } & \multicolumn{4}{c}{ Aktivitas sehari-hari } & \multirow{2}{*}{ Jumlah } \\
\cline { 2 - 5 } & Tidak berubah & $\%$ & Berubah & $\%$ & N \\
\hline Normal & 14 & 88 & 2 & 12 & 16 \\
Abnormal & 10 & 71 & 4 & 29 & 14 \\
\hline Jumlah & 24 & 80 & 6 & 20 & 30 \\
\hline $\mathrm{X}^{2}$ & & & &
\end{tabular}

$\mathrm{X}^{2}: 1,205 \quad$ df $: 1 \quad$ p 0,272 
prosedur pemeriksaan yang mengkhawatirkan (persepsi negatif). Hasil tersebut tidak berbeda bermakna baik pada kelompok bayi dengan hasil $\mathrm{pH}$ metri normal maupun pada kelompok bayi dengan hasil $\mathrm{pH}$-metri abnormal (75 vs 71\%, p > 0,05) (Tabel 5). Pemeriksaan $\mathrm{pH}$-metri kali ini merupakan pengalaman pertama bagi semua orangtua.

\section{Diskusi}

Data yang diperoleh melalui wawancara dengan orangtua tidak dipungkiri dapat menyebabkan bias penelitian. Oleh karena itu, pertanyaan yang diajukan untuk setiap kelompok lebih dari satu, sehingga diharapkan dapat mengurangi kemungkinan terjadinya bias.

Pada penelitian yang dilakukan pada anak, Colleti dkk. melaporkan sekitar 17\% (5/30) anak memperlihatkan perubahan pola makan selama prosedur pH-metri berlangsung. ${ }^{8}$ Penelitian yang kami lakukan pada bayi juga memperlihatkan hasil yang sama, yaitu $17 \%$. Jumlah bayi yang memperlihatkan perubahan pola makan baik pada kelompok bayi dengan $\mathrm{pH}$-metri normal maupun pada kelompok bayi dengan $\mathrm{pH}$-metri abnormal tidak berbeda bermakna (19\% dan 14\%). Hasil ini tidak bertentangan dengan laporan yang disampaikan oleh beberapa peneliti bahwa jenis makanan, frekuensi pemberian makan, dan jumlah makanan tidak mempengaruhi hasil pemeriksaan $\mathrm{pH}$ metri. ${ }^{3,9-11}$ Sebaliknya, Hegar dkk. ${ }^{12}$ dalam penelitiannya memperlihatkan bahwa hasil pemeriksaan $\mathrm{pH}$ metri dipengaruhi dari periode buffer lambung.

Pengamatan yang sama juga dilakukan terhadap aktivitas bayi. Pengamatan pada orang dewasa memperlihatkan bahwa prosedur $\mathrm{pH}$-metri mengurangi aktivitas fisik. ${ }^{4,13}$ Aktivitas lari menyebabkan episode refluks lebih sering dibanding latihan aerobik. ${ }^{14}$ Makin tinggi intensitas latihan fisik, makin bertambah episode refluks. ${ }^{15}$ Prosedur $\mathrm{pH}$-metri secara bermakna mengurangi aktivitas yang dapat memprovokasi RGE. ${ }^{15}$ Pengamatan yang dilakukan pada anak juga memperlihatkan bahwa aktivitas anak mempengaruhi jumlah dan lamanya episode refluks., ${ }^{4,14}$

Pada penelitian ini, hanya 6 bayi (20\%) yang memperlihatkan perubahan aktivitas selama prosedur pH-metri, dan 30\% (2/6) diantaranya dengan hasil $\mathrm{pH}$-metri normal. Begitu pula pada 24 bayi $(80 \%)$ lainnya yang tidak memperlihatkan perubahan aktivitas, 58\% (14/24) diantarannya mempunyai $\mathrm{pH}$ metri normal. Kedua data tersebut tidak berbeda bermakna. Dengan demikian prosedur $\mathrm{pH}$-metri tidak mengubah aktivitas bayi.

Prosedur $\mathrm{pH}$-metri, baik pada bayi dengan $\mathrm{pH}$ metri normal maupun bayi dengan $\mathrm{pH}$-metri abnormal tidak mempengaruhi persepsi orangtua terhadap prosedur pemeriksaan tersebut. ${ }^{6}$ Pada penelitian kami, hanya $25 \%$ orangtua dari bayi dengan $\mathrm{pH}$-metri normal mempunyai persepsi positif terhadap prosedur $\mathrm{pH}$ metri. Begitu pula pada bayi dengan hasil $\mathrm{pH}$-metri abnormal, hanya $29 \%$ orangtuanya mempunyai persepsi positif terhadap prosedur $\mathrm{pH}$-metri $(\mathrm{p}>0,05)$. Dengan demikian, $\mathrm{pH}$-metri sebagai prosedur pemeriksaan pada bayi hanya ditoleransi oleh kurang dari sepertiga orangtua. Berdasarkan jawaban kuesioner, kecemasan orangtua karena adanya kateter di dalam esofagus selama 24 jam yang akan menyakitkan anaknya. Kecemasan tersebut dapat disebabkan karena prosedur ini merupakan pengalaman pertama bagi orangtua. Adanya pengalaman sebelumnya dengan prosedur $\mathrm{pH}$-metri tentunya dapat mempengaruhi persepsi orangtua terhadap prosedur pemeriksaan tersebut. Data ini dapat menjadi masukkan bagi tenaga medis yang akan melakukan $\mathrm{pH}$-metri sebagai prosedur diagnostik RGE. Oleh karena prosedur $\mathrm{pH}$-metri sangat mencemaskan orangtua, maka selain informasi lengkap dan jelas setiap sebelum melakukan prosedur pemeriksaan, maka komunikasi antara tenaga medis dan orangtua harus selalu terjalin selama pemeriksaan berlangsung. $\mathrm{Hal}$

Tabel 5. Hubungan hasil $\mathrm{pH}$-metri dengan persepsi orangtua

\begin{tabular}{cccccc}
\hline \multirow{2}{*}{$\mathrm{pH}$-metri } & \multicolumn{4}{c}{ Persepsi orangtua } & \multirow{2}{*}{ Jumlah } \\
\cline { 2 - 5 } & Positif & $\%$ & Negatif & $\%$ & N \\
\hline Normal & 4 & 25 & 12 & 75 & 16 \\
Abnormal & 4 & 29 & 10 & 71 & 14 \\
\hline Jumlah & 8 & 27 & 22 & 73 & 30 \\
\hline $\mathrm{X}^{2}: 0,49 \quad \mathrm{df}: 1$ & $\mathrm{p} 0,825$ & & & &
\end{tabular}


tersebut penting agar orangtua dapat segera mendapat penjelasan tentang kecemasan yang dirasakan.

\section{Kesimpulan}

Kesimpulan dari penelitian ini, prosedur $\mathrm{pH}$-metri tidak mengubah pola makan dan akivitas pada lebih dari $80 \%$ bayi, walaupun demikian prosedur $\mathrm{pH}$-metri hanya ditoleransi oleh sekitar $27 \%$ orangtua.

\section{Daftar Pustaka}

1. Hegar B, Vandenplas Y. Gastroesophageal reflux in infancy. J Gastroenterol Hepatol 1999; 14:13-9.

2. Branicki FJ, Evans DF, Ogilvie AL, Atkinson M, Hardcastle JD. Ambulatory monitoring of oesophageal $\mathrm{pH}$ in reflux oesophagitis using a portable radiotelemetry system. Gut 1982; 23:992-8.

3. Vandenplas Y, DeWolf D, Deneyer M, Sacre L. Incidence of gastro-esophageal reflux in sleep, awake, fasted and postcibal periods in asymptomatic and symptomatic infants. J Pediatr Gastroenterol Nutr 1988; 7:177-81.

4. Mearin FJ, Balboa A, Dot J, Maldonado O, Malagelada JR. How standard is a standard day during a standard ambulatory 24-hour esophageal $\mathrm{pH}$ monitoring?. Scand J Gastroenterology 1998; 33:583-5.

5. Vandenplas Y, Belli D, Boige N, Bouquet J, Cadranel S, Cezard JP, et al. A Standardized protocol for the methodology of esophageal $\mathrm{pH}$ monitoring and interpretation of the data for the diagnosis of gastroesophageal reflux. (ESPGHAN-society statement). J Pediatr Gastroenterol Nutr 1992; 14:467-71.

6. Vandenplas Y, Goyvaerts H, Helven R. Gastro-esophageal reflux, as measured by 24-hour $\mathrm{pH}$ monitoring, in 509 healthy infants screened for SIDS-risk. Pediatrics 1991; 88:834-40.

7. Arana A, Hauser B, Hegar B, Kaufman L, Vandenplas Y. Oesophageal $\mathrm{pH}$ monitoring in children: How is it perceived by the parents and does the technique change feeding and daily activity ?. Acta Paediatr 2003; 92:1021-25

8. Coletti RB, Christie DL, Orenstein SR. Statement of the North American Society for Pediatric Gastroenterology and Nutrition (NASPGAN). Indications for pediatric esophageal $\mathrm{pH}$ monitoring. J Pediatr Gastroenterol Nutr 1995; 21:253-62.

9. Nebel OT, Castell DO. Lower oesophageal sphincter pressure changes after food ingestion. Gastroenterology 1972; 63:778-83.

10. Becker DJ, Sinclair J, Castell DO, Wu WC. A comparison of high and low fat meals on postprandial oesophageal acid exposure. Am J Gastroenterology 1989; 84:782-6.

11. Vandenplas Y, Sacre L, Loeb H. Effects of formula feeding on gastric acidity time and oesophageal $\mathrm{pH}$ monitoring data. Eur J Pediatr 1988; 148:152-4.

12. Hegar B, Vandemaele K, Arana Alvaro, Vandenplas Y. Oesophageal $\mathrm{pH}$ monitoring in infants: Elimination of gastric buffering does not modify reflux index. J Gastroenterol Hepatol 2000; 15:902-5

13. Fass R, Hell R, Sampliner RE, Pulliam G, Graver E, Hartz V, et al. Effect of ambulatory 24-hour esophageal $\mathrm{pH}$ monitoring on reflux-provoking activities. Dig Dis Sci 1999; 44:2263-9.

14. Clark S, Kraus BB, Sinclair J, Castell DO. Gastroesophageal reflux induced by exercise in healthy volunteers. JAMA Med Assoc 1989; 261:3599-601.

15. Soffer EE, Merchant RK, Duethman G, Launspach J, Gisolfi C, Adrian T. Effect of graded exercise on esophageal motility and gastroesophageal reflukx in trained athletes. Dig Dis Sci 1993; 38:220-4. 